\title{
Changes in Animal Activity Prior to a Major ( $M=7)$ Earthquake in the Peruvian Andes
}

\author{
Rachel A. Grant ${ }^{1,6^{*}}$, Jean Pierre Raulin ${ }^{2}$, and Friedemann T. Freund ${ }^{3,4,5}$
}

1. Department of Life Sciences, Anglia Ruskin University, East Rd, Cambridge, CB11PT, UK. Rachel.grant@anglia.ac.uk

2. CRAAM, Presbyterian MacKenzie University, São Paulo, Brasil

3. Department of Physics, San Jose State University, San Jose, CA 95192, USA

4. Carl Sagan Center, SETI Institute, Mountain View, CA 94043, USA

5. NASA Ames Research Center, Moffett Field, CA 94035, USA.

6. Department of Animal and Land Sciences, Hartpury College, Hartpury, Gloucester GL19 3BE, England, UK

Corresponding author: Rachel Grant rachelannegrant@gmail.com; Rachel.grant@hartpury.ac.uk

\begin{abstract}
During earthquake preparation geophysical processes occur over varying temporal and spatial scales, some leaving their mark on the surface environment, on various biota, and even affecting the ionosphere. Reports on pre-seismic changes in animal behaviour have been greeted with scepticism by the scientific community due to the necessarily anecdotal nature of much of the evidence and a lack of consensus over possible causal mechanisms. Here we present records of changes in the abundance of mammals and birds obtained over a 30 day period by motiontriggered cameras at the Yanachaga National Park, Peru, prior to the 2011 magnitude 7.0 Contamana earthquake. In addition we report on ionospheric perturbations derived from nighttime very low frequency (VLF) phase data along a propagation paths passing over the epicentral region. Animal activity declined significantly over a 3-week period prior to the earthquake compared to periods of low seismic activity. Night-time ionospheric phase perturbations of the VLF signals above the epicentral area, fluctuating over the course of a few minutes, were observed, starting 2 weeks before the earthquake. The concurrent observation of two widely different and seemingly unconnected precursory phenomena is of interest because recently, it has been proposed that the multitude of reported pre-earthquake phenomena may arise from a single underlying physical process: the stress-activation of highly mobile electronic charge carriers in the Earth's crust and their flow to the Earth's surface. The flow of charge carriers through the
\end{abstract}


rock column constitutes and electric current, which is expected to fluctuate and thereby emit electromagnetic radiation in the ultralow frequency (ULF) regime. The arrival of the charge carriers can lead to air ionization at the ground-to-air interface and the injection of massive amounts of positive airborne ions, known to be aversive to animals.

\section{Introduction}

Earthquake preparation periods are associated with geophysical changes that manifest themselves over varying temporal and spatial scales [Ryabinin et al. 2011; Shitov 2010]. During the lead-up to major earthquakes non-seismic pre-earthquake (pre-EQ) phenomena have often been reported, including perturbations in the ionosphere [Pulinets \& Boyarchuk 2004; Liperovsky 2000], thermal infrared anomalies [Saraf et al. 2008; Tramutoli et al. 2005; Tronin 2006], ultralow frequency emissions [Hayakawa 2000], earthquake lights [Derr 1973, St-Laurent 2000], and unusual animal behaviour [Tributsch, 1984; Buskirk et al. 1981].

Unusual animal behaviour has been reported for centuries, even millennia [Tributsch, 1984]. While most evidence has been provided by post-hoc reports, which may be biased due to selective recollection and subjective interpretation, there are often striking similarities among reports from different seismically active regions of the Earth through the centuries, giving them some credibility [Whitehead et al. 2004]. Nonetheless, most mainstream scientific community has greeted any report of unusual animal behaviour before major earthquakes with great scepticism. The main objection has always been that the evidence presented was mostly anecdotal and that systematically collected data were rare, although some rigorous studies have been published relating to humans [Shitov 2010]; ants [Berberich 2014]; primates [Snarr 2005], amphibians, [Grant \& Halliday 2010; Grant et al. 2011] and rodents [Yokoi et al. 2003; Li et al. 2009]. The described pre-earthquake responses range from no apparent behavioural changes to distinct and significant behavioural changes. However, the infrequency and unpredictability of earthquakes means that most relevant pre-earthquake studies suffer, of necessity, from small sample sizes and from difficulties with reproducibility under comparable conditions. Seismo-ionospheric disturbances often appear a few days or weeks prior to large earthquakes [Liu 2006], and can be detected by various methods including analysis of very low frequency (VLF) radiowave anomalies.

Prior to the $2009 \mathrm{M}=6.3 \mathrm{~L}$ 'Aquila earthquake unusual toad behaviour was reported about $75 \mathrm{~km}$ from the epicentre, coincident with perturbations in the ionosphere detected by VLF radio sounding [Grant \& Halliday 2010]. The concurrent observation of two precursory phenomena, 
which seem to have no direct connection, is of interest because recently, it has been proposed that the many reported, diverse pre-EQ phenomena most likely arise from a single underlying physical process, namely the stress-activation of highly mobile, positive electronic charge carriers in the Earth's crust and their flow to the Earth's surface. As they flow into water they cause electrochemical reactions, which lead to changes in water chemistry. As they accumulate on the surface, they cause field-ionization of air molecules and the injection of massive amounts of positive airborne ions at the ground-to-water interface, which change the electric field in the atmosphere and affect the electron distribution in the ionosphere [Freund 2013].

\section{Methods}

\section{The study site}

The Yanachaga National Park $\left(10.3690^{\circ} \mathrm{S}, 75.3700^{\circ} \mathrm{W}\right)$ is located on the eastern slope of the Andean Cordilleras toward the Amazon basin, in a small mountain range of lesser altitude, the Cordillera de Yanachaga, separated from the Andes by valleys. The elevation in the area ranges from $460-3450 \mathrm{~m}$. The yearly average temperature is $19^{\circ} \mathrm{C}$ with variations controlled by altitude. Rainfall occurs all year round, more heavily between November and April, but there is no particular dry season and the vegetation remains evergreen. Mainly Mesozoic and early Tertiary sedimentary rocks are exposed in the sub-Andean Cordilleras. At the western part of the Cordillera de Yanachaga older rock formations prevail, primarily Permian, while the northern part is composed primarily of upper Triassic and lower Jurassic rocks along with various Cretaceous formations.

\section{The Contamana earthquake}

The Contamana earthquake of magnitude of 7.0 occurred on the $24^{\text {th }}$ August 2011 at 12.46 local time, with its epicentre $323 \mathrm{~km}$ from Yanachaga National Park. The seismicity in the region results from the convergence of Nazca and South American plates, the present earthquake being a result of the underthrusting Nazca slab, which stressed the overlying crust [Tavera, 2012]. The 
earthquake hypocenter was at $134 \mathrm{~km}$. Although moderate earthquakes at this depth range are usually not felt, when they are as large as magnitude 7, they lead to a particularly wide area of perception [Tavera, 2012]. In the case of the Contamana earthquake, the shock was felt as far as 700km away, extending into the Andean Cordillera, from where strong shaking was reported [Tavera, 2012]. Table1 shows the seismic events in the region, their magnitude and their distance from the National Park.

Table 1. Earthquakes of $M=4.5$ and greater within $350 \mathrm{~km}$ of the Yanachaga National Park. Source: USGS circular earthquake search facility. The shaded row indicates the $M=7$ event.

$\begin{array}{crrrrrrr}\text { YEAR } & \text { MONTH } & \text { DAY } & \text { LATITUDE } & \text { LONGITUDE } & \text { DEPTH } & \text { MAGNITUDE } & \text { DISTANCE } \\ 2011 & 1 & 22 & -12.15 & -73.06 & 33 & 5.1 & 296 \\ 2011 & 2 & 1 & -10.69 & -76.29 & 111 & 4.7 & 120 \\ 2011 & 3 & 27 & -8.7 & -74.62 & 132 & 4.8 & 208 \\ 2011 & 6 & 4 & -7.74 & -74.63 & 141 & 5.2 & 310 \\ 2011 & 6 & 12 & -8.68 & -75.23 & 140 & 4.8 & 200 \\ 2011 & 6 & 22 & -11.27 & -73.39 & 14 & 4.5 & 214 \\ \mathbf{2 0 1 1} & \mathbf{8} & \mathbf{2 4} & -\mathbf{7 . 6 4} & -\mathbf{7 4 . 5 3} & \mathbf{1 4 7} & \mathbf{7} & \mathbf{3 2 3} \\ 2011 & 8 & 24 & -7.77 & -74.53 & 140 & 5.4 & 309 \\ 2011 & 9 & 17 & -7.76 & -74.57 & 144 & 4.5 & 309 \\ 2011 & 9 & 23 & -11.88 & -75.92 & 90 & 4.5 & 172 \\ 2011 & 10 & 11 & -11.15 & -73.79 & 37 & 4.7 & 170 \\ 2011 & 10 & 30 & -9.39 & -75.36 & 32 & 4.9 & 123 \\ 2011 & 11 & 22 & -8.21 & -74.13 & 157 & 4.6 & 278 \\ 2011 & 11 & 26 & -10.71 & -78.19 & 51 & 5.1 & 327 \\ 2011 & 12 & 19 & -12.2 & -77.09 & 53 & 4.7 & 279\end{array}$

\section{Motion Triggered Camera Observations}

The Tropical Ecology Assessment and Monitoring (TEAM) Network routinely operates camera traps in numerous tropical locations, generally within national parks and conservation areas, for 
the purpose of wildlife monitoring and census. The Yanachaga National Park participates in the TEAM activities and its rangers routinely operate clusters of motion-triggered camera traps. The time-stamped photos, stored along with other data such as temperature and moon phase [Kays et al. 2010], are publicly available and were downloaded from the Tropical Ecology Assessment and Monitoring (TEAM) Network website www.teamnetwork.org. In this study, we analysed the numbers of animals captured on photographs by a cluster of 9 motion-triggered cameras. The $9-$ camera cluster operated uninterrupted $24 \mathrm{~h}$ per day for nearly 30 days, from 27/07/2011 to 25/08/2011, the day after the M7 Contamana earthquake. The Reconyx trail cameras (www.reconyx.com) took pictures automatically whenever animal movements were detected via infrared flashes, which are believed not to disturb the animals or affect their behaviour. The photos provide images that can be analyzed free from human interference and subjective interpretation. Such images can be considered a permanent record, analogous in rigor to museum specimens [Kays 2010]. The camera cluster had been placed on a $900 \mathrm{~m}$ high ridge in the Yanachaga National Park, Peru, as depicted in Figure 1. The M=7.0 Contamana earthquake occurred on 24/08/2011 at a depth of $134 \mathrm{~km}$ and a distance of about $320 \mathrm{~km}$ from the Park.

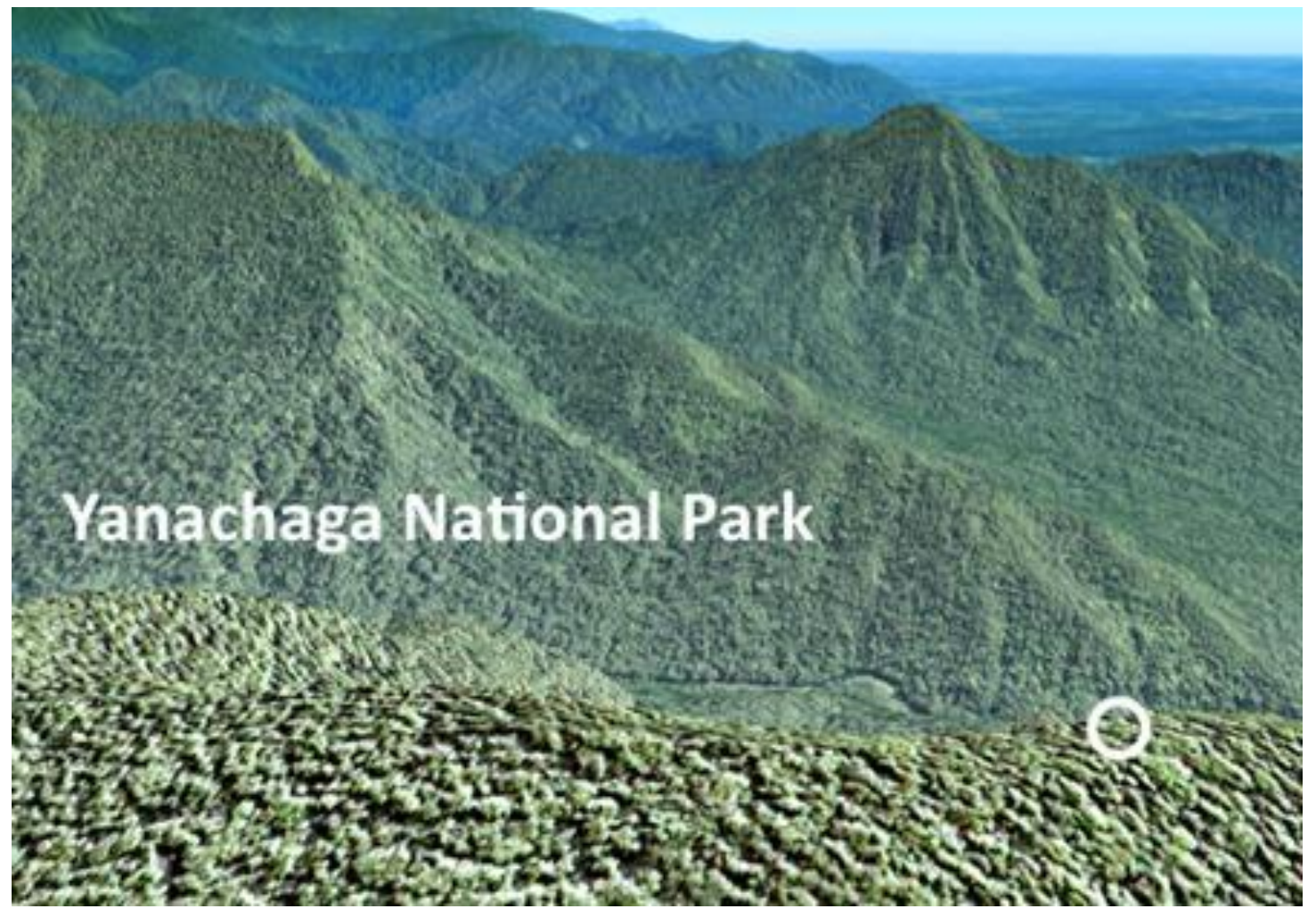

Figure 1: NASA's WorldWind representation the Yanachaga National Park on the East side of the Peruvian Andes overlooking the Amazon basin. The location of the cluster of 9 motiontriggered cameras, marked by the white circle, was on a ridge at an elevation of about $900 \mathrm{~m}$. 
The serial numbers of these cameras, their locations and dates of operation are shown in the supplementary material. Camera traps were operational $24 \mathrm{~h}$ per day from 17/07/2011 to 19/10/2011. During this period, with the exception of the M7 Contamana earthquake of 24/8/2011 (and an aftershock on the same day), no seismic activity of magnitude above 5 was recorded within $350 \mathrm{~km}$ of the Yanachaga Park. Nine camera traps were in continuous and simultaneous operation from $24 / 7 / 11$ to $25 / 8 / 11$, the day after the event. After the earthquake, the photographic record was interrupted from $25 / 08 / 11$ to 31/08/11. In the national park, the deployment of camera traps is staggered so they are not all operating simultaneously or continuously. As this would cause bias, we selected two time periods for analysis, when a number of camera traps were operating simultaneously and continuously for an (approximate) 4 week period. The day after the earthquake, unfortunately co-incided with most of the camera traps being taken down by national park rangers so no data were available for the period immediately after the earthquake. Data from all nine cameras were pooled. For control we chose data from a 10-camera cluster during a period of low seismic activity, at similar longitude and latitude from13/09/2011 to 11/10/2011. The available data set consists of 1359 photographic records for the earthquake period and 1491 for the control period.

The parameters analysed were as follows:

\section{Number of animals recorded per 24 hour period}

Records were not counted when an animal was not identifiable because the photograph was too dark or the animal could not be seen clearly enough for unequivocal identification. The remaining dataset was sorted by date. The number of animals recorded per 24 hour period was calculated. Following the method of Kay et al. (2010)] who analysed TEAM Network camera trap data from Costa Rica, animal movements within 30 seconds of previous triggers by the same species and at the same location were assumed to be caused by the same animal and discounted. A limitation of this specific analysis is that the same animal may sometimes be recorded more than once if it moves back into the area after a 30 second gap. Visual inspection of the data, however, revealed this effect to be relatively minor.

\section{Taxonomic composition}


Taxonomic composition has been shown to change in connection with earthquakes [Brancelj et al. 2012]. Two orders of ground dwelling birds (galliformes and tiniamiformes) and six orders of terrestrial mammals (carnivora, cetartiodactyla, cingulata, perissodactyla, primates and rodentia) were recorded on camera during the study period. The number of animals recorded was calculated for each day and plotted to illustrate the relative taxonomic composition.

\section{Statistical Analysis}

A control date was designated one day before the end of the control period (analogous to the earthquake date one day before the end of the earthquake period). Moon phase data were obtained from the US Naval Observatory (www.usno.navy.mil). Moon phase was modelled using periodic regression [Batschelet 1981, Debruyn \& Meeuwig 2001,SenGupta \& Ugwuowo 2007]. The number of days since the last full moon was converted to an angular measurement (f) by the formula $f=2 p(t / T)$, where $t$ is the days of the lunar cycle and $T$ is the period (which in this case is the length of the lunar cycle, i.e. 29.53 days; however, to avoid having 0.53 of a day, 30 was used here). The sine and the cosine of the angle were used to test the effect of moon phase on the dependent variables. Temperatures were calculated by taking the mean of the temperature recorded on each camera trap for a particular date. On dates where no animals were seen, temperature data were taken from a nearby camera trap. No temperature data are available for the day of the earthquake as no animals were active on any camera trap in the park. The last temperature recorded from any camera trap in the park was on 23/08/2011 at 20:24:39 and the temperature was 18 Celsius, which was used in the analysis. The number of number of animals (numa) was modelled using the following independent variables : (i) temperature (avtemp), (ii) the sine of the moon angle (sinangle) (iii) the cosine of the moon angle (cosangle), and (iii) days to earthquake or to the control date (daysb)). Data were analysed with negative binomial regression using Small Stata 11. After running separate regression models for control / baseline and earthquake period, the difference between the regression coefficients was tested using Stata's postestimation tools, specifically "suest", which tests for differences in coefficients.

\section{VLF-ULF anomalies}

VLF-ULF anomalies, indicating disturbances in the ionosphere, have been noted before numerous earthquakes and normally occur only in connection with moderately large earthquakes 
with M> 6 [Maekawa et al. 2006; Dabas et al. 2007]. The South American VLF Network (SAVNET)) is a network of very low frequency (VLF) receivers in Brazil, Peru and Argentina [ Raulin 2009]. The SAVNET VLF array tracks phase and amplitude of VLF waves which reflect in the D-region $(\sim 70 \mathrm{~km})$, and the bottom E-region $(\sim 85-90 \mathrm{~km})$, during daytime and night-time periods, respectively. We present night-time Very Low Frequency (VLF) phase data for the 4month period from 01 June to 31 Oct. 2011 for a propagation path from the transmitter station NAA in Northern Canada $\left(44^{\circ} 38^{\prime} 47.02^{\prime \prime} \mathrm{N} 67^{\circ} 16^{\prime} 51.85^{\prime \prime} \mathrm{W}\right)$ to the receiver station PLO in Peru that passes close to the Yanachaga Park, within the expected range of influence (earthquake preparation zone) for a magnitude 7 event. As control we use a propagation path from NAA received at the Caselo Observatory (CAS) in Argentina far to the East. The map with the 2 propagation paths is presented in Figure 2. During the period of interest, during the last 4 weeks before the Contamana event and longer, there was no geomagnetic storm activity and no major seismic activity $(M>5)$ occurred along the two propagation paths between NAA - PLO and NAA - CAS apart from the Contamana Earthquake. 


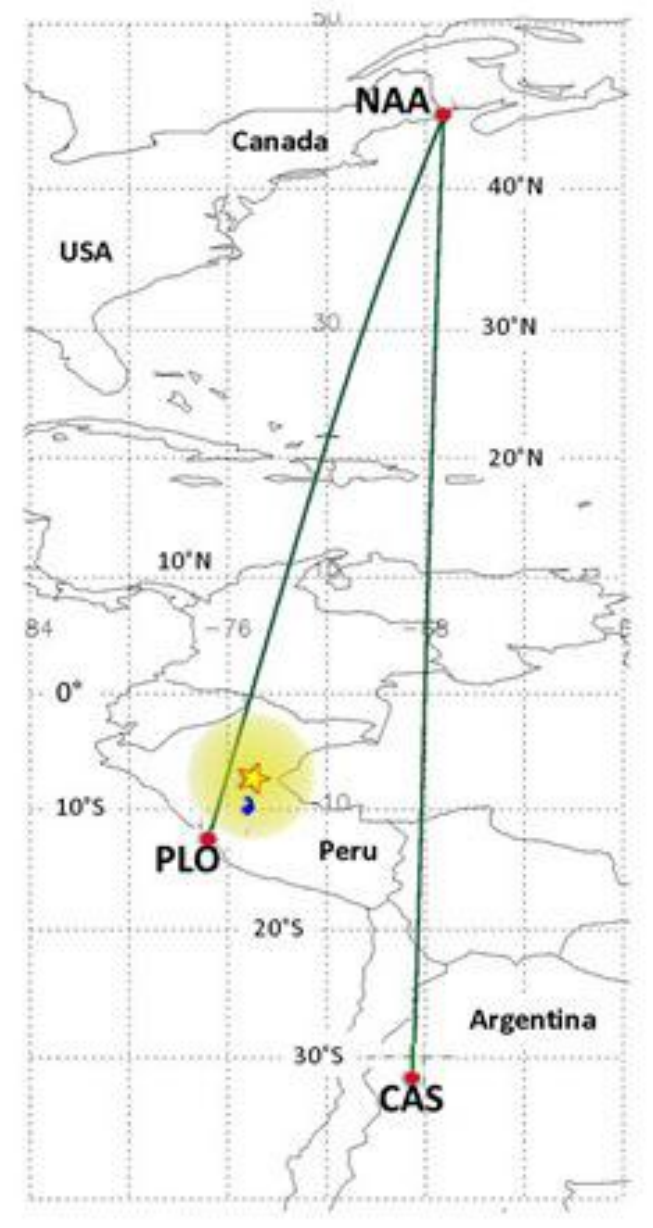

Figure 2. Great-Circle projection of the VLF radiowave propagation paths used in the analysis from the transmitter station NAA in Northern Canada to receiver stations PLO and CAS in Peru and Argentina, respectively. The epicentre of the contamana earthquake is shown as a star and the blue symbol shows the location of the Yanachaga National Park

\section{Results}

\section{Number of animals recorded per day}

The number of animals recorded on the camera traps started to decrease about 23 days before the earthquake with the decrease accelerating 8 days prior to the earthquake (Figure 3). On days 10, $6,5,3$ and 2 prior to the earthquake and on the day of the earthquake no animal movements were recorded, which is highly unusual for this mountainous rainforest region of the Yanachaga National Park. Regression analysis shows a significant drop in animal numbers for the earthquake period but not the control period (Table 3). Comparison of the regression coefficients 
of the two models show a highly significant difference [Chi2 $(1)=14.68 ;$ Prob $>$ chi2 $=0.0001]$ indicating a distinct difference in the slope of the regression lines.
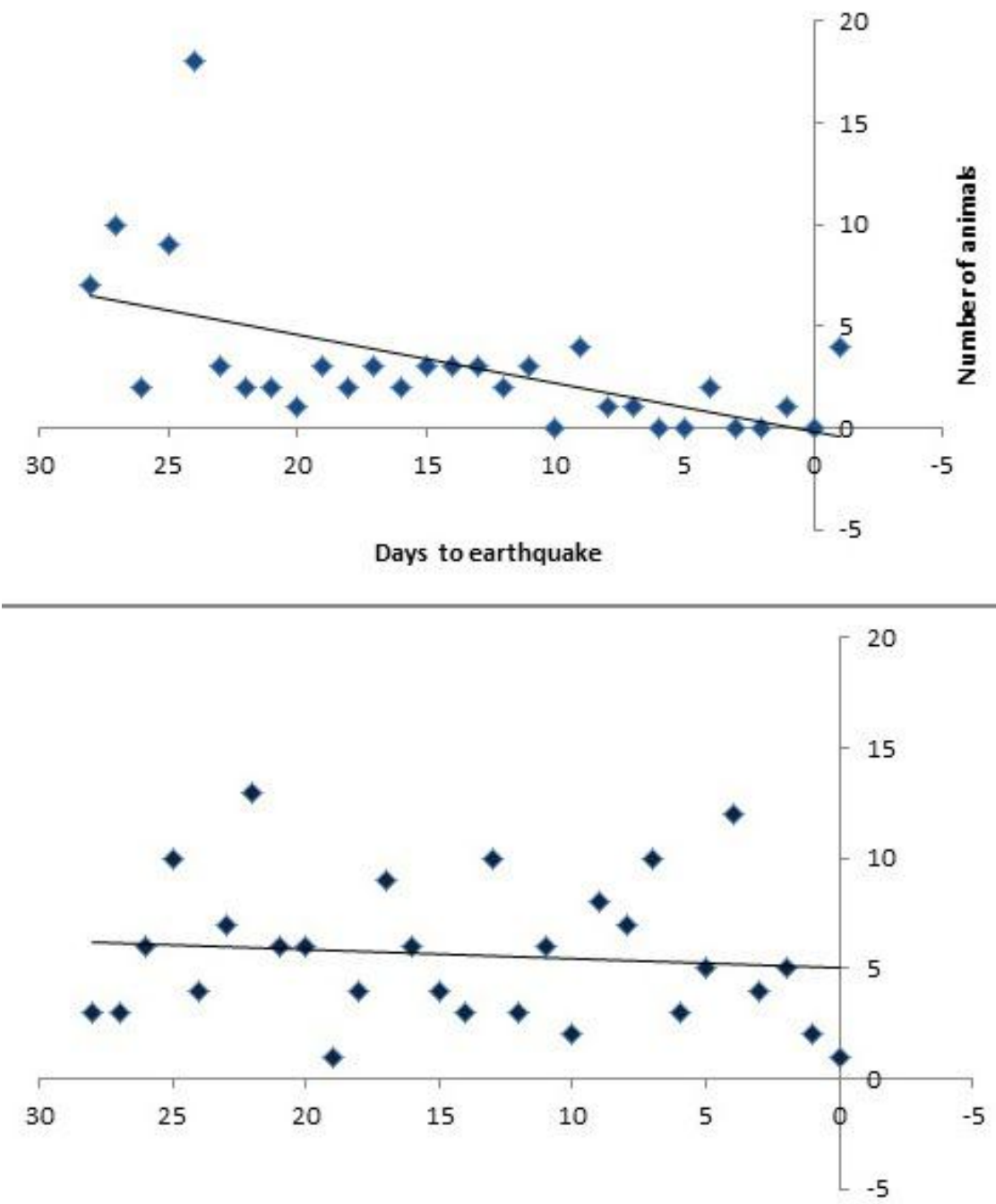

Figure 3 top: Number of individual animals recorded on camera traps in Yanachaga National Park. The $M=7$ event occurred on 24/8/11(day 0); bottom: Control (control date shown as day 0)

\begin{tabular}{|c|c|c|c|c|c|c|}
\hline \multicolumn{7}{|c|}{ EARTHQUAKE PERIOD } \\
\hline $\mathrm{N}=29$ & $\begin{array}{l}\text { Prob > } \\
\text { chi2= } \\
0.0000\end{array}$ & $\begin{array}{l}\text { Log likelihood = - } \\
51.92621\end{array}$ & & & & \\
\hline$\frac{\text { numa (EQ }}{\text { period) }}$ & $\underline{\text { Coefficient }}$ & $\underline{\text { Std. Err. }}$ & $\underline{\mathrm{z}}$ & $\underline{\mathrm{p}>|z|}$ & \multicolumn{2}{|c|}{$95 \%$ Conf. Interval } \\
\hline daysb & 0.0966007 & 0.0198131 & 4.88 & 0.000 & 0.0577678 & $\mathbf{0 . 1 3 5 4 3 3 6}$ \\
\hline cosangle & -0.2235902 & 0.1970702 & -1.13 & 0.257 & -0.6098407 & 0.1626603 \\
\hline
\end{tabular}




\begin{tabular}{|l|l|l|l|l|l|l|}
\hline sinangle & -0.4294768 & .2401541 & -1.79 & 0.074 & -0.9001701 & 0.0412166 \\
\hline avtemp & .0021869 & .0811295 & 0.03 & 0.978 & -0.1568241 & 0.1611978 \\
\hline cons & -.7568119 & 1.829305 & -0.41 & 0.679 & -4.342184 & 2.82856 \\
\hline
\end{tabular}

\section{CONTROL PERIOD}

\begin{tabular}{|l|l|l|l|l|l|l|}
\hline $\mathrm{N}=29$ & $\begin{array}{l}\text { Prob }>\text { chi2 } \\
=0.3719\end{array}$ & $\begin{array}{l}\text { Log likelihood } \\
-70.434266\end{array}$ & & & & \\
\hline $\begin{array}{l}\text { numa } \\
\frac{\text { control }}{\text { period })}\end{array}$ & $\underline{\text { Coefficient }}$ & $\underline{\text { Std. Err. }}$ & $\underline{\mathrm{Z}}$ & $\underline{\mathrm{P}>|\mathrm{z}|}$ & $\begin{array}{l}\text { 95\% Conf. } \\
\text { Interval }\end{array}$ & \\
\hline daysb & .0096899 & .0119628 & 0.81 & 0.418 & -.0137567 & .0331364 \\
\hline cosangle & -.1815771 & .1620708 & -1.12 & 0.263 & -.4992301 & .1360759 \\
\hline sinangle & -.1706743 & .1561537 & -1.09 & 0.274 & -.4767299 & .1353813 \\
\hline avtemp & $\mathbf{- . 2 5 4 4 6 2 5}$ & $\mathbf{. 1 2 6 3 9 1}$ & $\mathbf{- 2 . 0 1}$ & $\mathbf{0 . 0 4 4}$ & $\mathbf{- . 5 0 2 1 8 4 3}$ & $\mathbf{- . 0 0 6 7 4 0 7}$ \\
\hline cons & 6.776161 & 2.566202 & 2.64 & 0.008 & 1.746498 & 11.80582 \\
\hline
\end{tabular}

Table 3. Negative binomial regression outcomes for number of animals (numa) for the earthquake period and the control period. Significant outcomes are shown in bold.

\section{Taxonomic composition}

A striking result of the observations reported here is (i) that the level of animal activity started to decline as early as 23 days before this major earthquake and (ii) that the numbers of animals captured on camera dropped even more significantly 8 to 10 days before the event with rodents, the most abundant animals in this tropical forest environment, almost completely disappearing as the earthquake approached (Figure 4). The time periods noted in our study, 20-22 days and 7-8 days before the event, is of interest because they correspond to the time periods of biotic changes reported to have occurred prior to other earthquakes as well [Shitov 2010; Whitehead \& Ulusoy 2013]. 

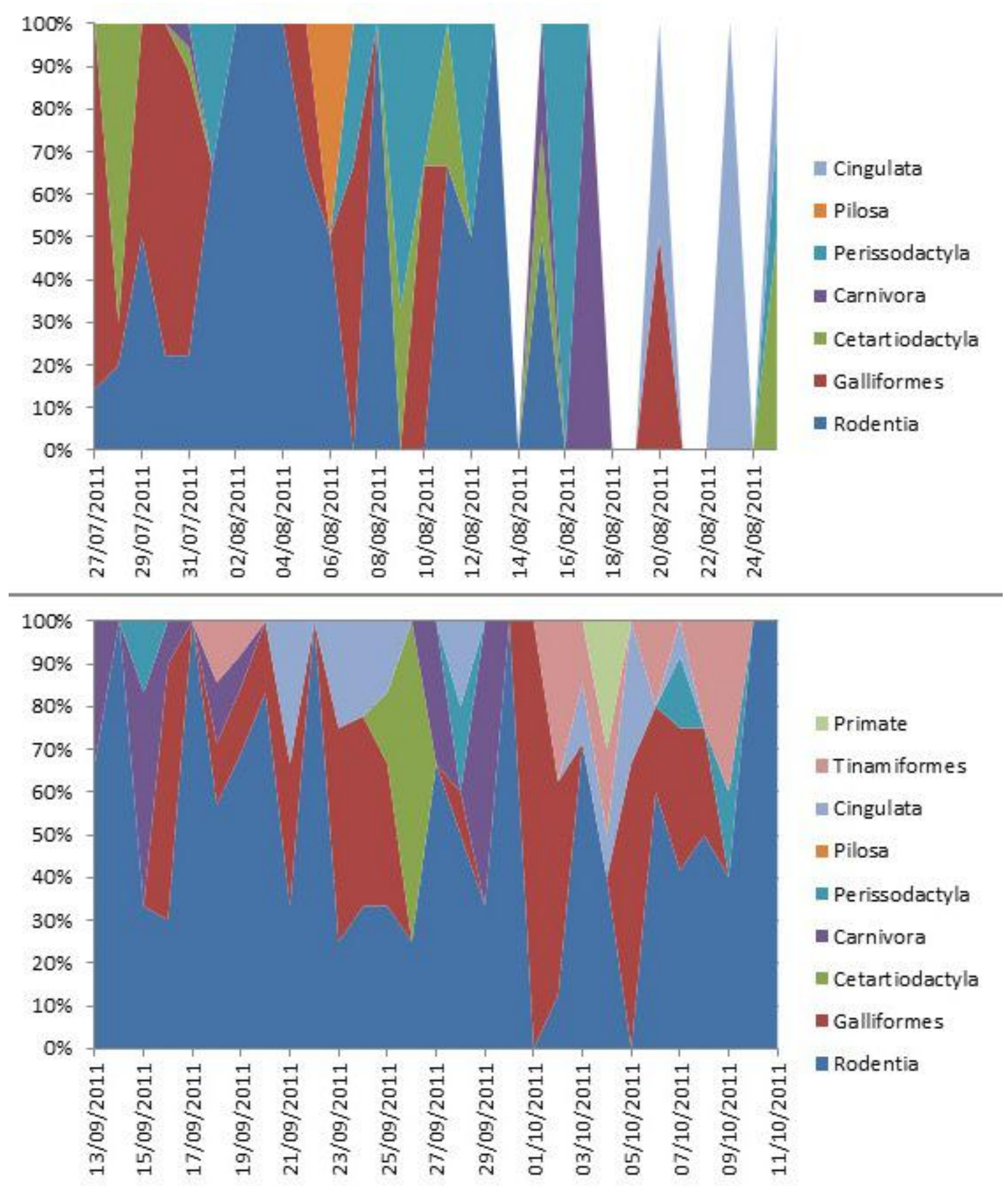

Figure 4. Relative abundance of various orders of vertebrates recorded in Yanachaga National Park during the pre-earthquake period under study (top) and a typical control period (bottom). The $M=7$ event occurred on 24/08/2011. The control period was from 13/09/2011 to 10/10/2011. 


\section{VLF Radiowave anomaly indicating ionospheric disturbance}

Strong ionospheric phase perturbations were noted starting 2 weeks before the EQ with fluctuations on the time scale of 2-4 minutes (Figure 5). A particularly large fluctuation was recorded on the NAA-PLO path around 8 days prior to the Contamana earthquake, coincident with the second sharp decrease in animal numbers observed in the pre-earthquake period.

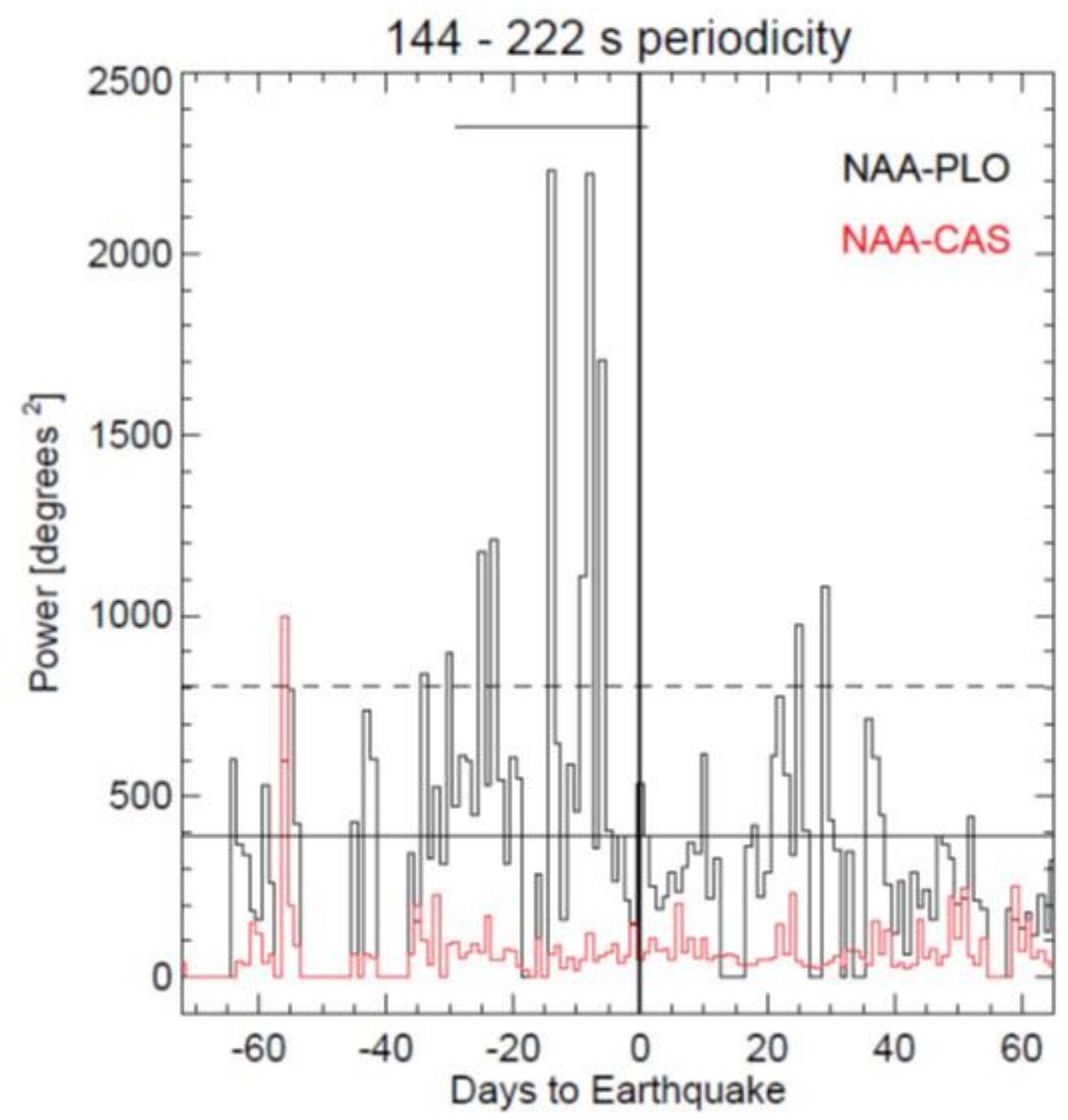

Figure 5. Magnitude of VLF radiowave disturbances for NAA-PLO passing near the epicentre (black) and NAA-CAS control path (red). Black vertical line indicates the date of the $M=7$ Contamana earthquake, which was the only large earthquake in the period, although many small $M<5$ also occurred which would not normally be expected to cause ionospheric perturbations. Solid horizontal line $=$ mean $+1 \sigma($ dotted line $)$. Horizontal bar indicates the dates for which camera trap data were available. 
The preparation of a major earthquake is marked by increasing mechanical stresses, normally in the brittle part of the Earth's crust down to a depth of $35-45 \mathrm{~km}$, but occasionally coming from much greater depth such as in the case of the Contamana earthquake. The mechanical stresses or other effects coming from stress-related processes spread out over a large rock volume, causing a wide area at the surface of the Earth to be affected. When the stresses at depth exceed the failure strength of the rocks in and around the hypocenter, catastrophic ruptures and, hence, earthquakes can occur.

Past experience has shown that there are no reliable seismic foreshocks, indicating that there is no pattern of smaller subvolumes of rock around the future hypocenter undergoing catastrophic rupture prior to the main event. Therefore, foreshock activity cannot be used in any statistically significant way as a warning sign for the approach of major earthquakes.

However, many aseismic or non-seismic precursors have been reported [Shitov, 2010; Pulinets \& Boyarchuk 2004; Liperovsky 2000; Saraf et al. 2008; Tramutoli et al. 2005; Tronin 2006; Hayakawa 2000; Derr 1973; St-Laurent 2000; Tributsch 1984; Buskirk et al. 1981], and they seem to occur much more reliably before major earthquakes. The data presented here indicate that, for instance, in the Yanachaga National Park some $320 \mathrm{~km}$ from the epicentre of the magnitude 7 event, animals were able to perceive some changes in their environment, which altered their behaviour. Through the ages rodents have often been mentioned in anecdotal reports of anomalous pre-earthquake animal behaviour [Tributsch, 1984]. Some recent systematic studies indeed suggest rodent sensitivity to pre-seismic cues. For example the locomotory activity of laboratory mice, recorded with automated equipment, increased significantly the day before the M=7.3 Kobe earthquake in 1995 [Yokoi et al. 2003], and the circadian rhythms of laboratory mice were in disarray 2-3 days before the $\mathrm{M}=8$ Wenchuan earthquake in 2008 [Li et al. 2009]. At the Yanachaga National Park site ground-dwelling galliform birds and even-toed ungulates were also seen in lower numbers prior to the $M=7$ Contamana earthquake. These taxa have not been mentioned before in connection with seismic activity. Cingulata (armadillos) that might be particularly sensitive to environmental conditions because they are a burrowing taxon, continued to be active. For reasons currently unknown, they were captured on camera even during the last few days before this earthquake, though their numbers were low.

\section{Possible mechanisms for the biotic change}


Past attempts to identify possible triggers of unusual pre-earthquake animal behaviour have mostly focused on mechanical stimuli, such as barely perceptible ground vibrations or olfactory stimuli believed to come from gases that would escape from the ground due to microfracturing of the rocks below. We focus on an entirely different physical process that has not yet attracted enough attention.

Igneous and high-grade metamorphic rocks, which form the bulk of the rocks deep in the Earth's crust, contain dormant peroxy defects in their constituent minerals. These defects are electrically inactive, but become activated when mechanical stresses are applied such during the build-up of tectonic stresses prior to earthquakes. The peroxy defects release highly mobile electronic charge carriers, which are - from a physics perspective - defect electrons in the oxygen anion sublattice, known as positive holes [Freund 2013]. From a chemistry perspective they are $\mathrm{O}^{-}$in a matrix of $\mathrm{O}^{2-}$, and as such highly oxidizing $\bullet \mathrm{O}$ radicals.

Once activated by stress, positive holes have the remarkable ability to be highly mobile and to spread out of the stressed rock volume into the surrounding unstressed or less stressed rocks. Positive holes spread fast, with speeds up to $100 \mathrm{~m} / \mathrm{s}$, and far, tens of $\mathrm{km}$, probably further. They affect wide surface areas. Because they all carry the same charge, they repel each other electrostatically and tend to accumulate at the topographic highs. Positive holes lead to a plethora of secondary reactions, including field-ionization of air molecules at the ground-to-air interface, injecting massive amounts of positive airborne ions into the lower atmosphere [Freund et al., 2009]. However, the air bubble laden with positive airborne ions is expected to expand upward to stratospheric heights, causing a downward polarization of the ionospheric plasma and increase in the Total Electron Content (TEC) at the lower edge of the ionosphere [Freund 2013].

It has been proposed that positive ions would drift upward in the prevailing global electric field through the atmospheric column up to the mesosphere as illustrated in Figure 6. During its rise through the mesosphere the initially homogeneous vertical ion current will break up into cells of different charge densities due to magnetohydrodynamic coupling to the Earth's dipole field [Freund 2013]. The continuing rise of these cells, probably achieving a terminal velocity on the order of 20-30 m/sec, will cause a granularity and a dynamic response of the ionospheric plasma, detectable by VLF radio sounding, turbulences in the electric field [Freund 2013], and a Doppler shift of the radio waves reflected off the lower edge of the ionosphere [Hayakawa et al. 2013]. 


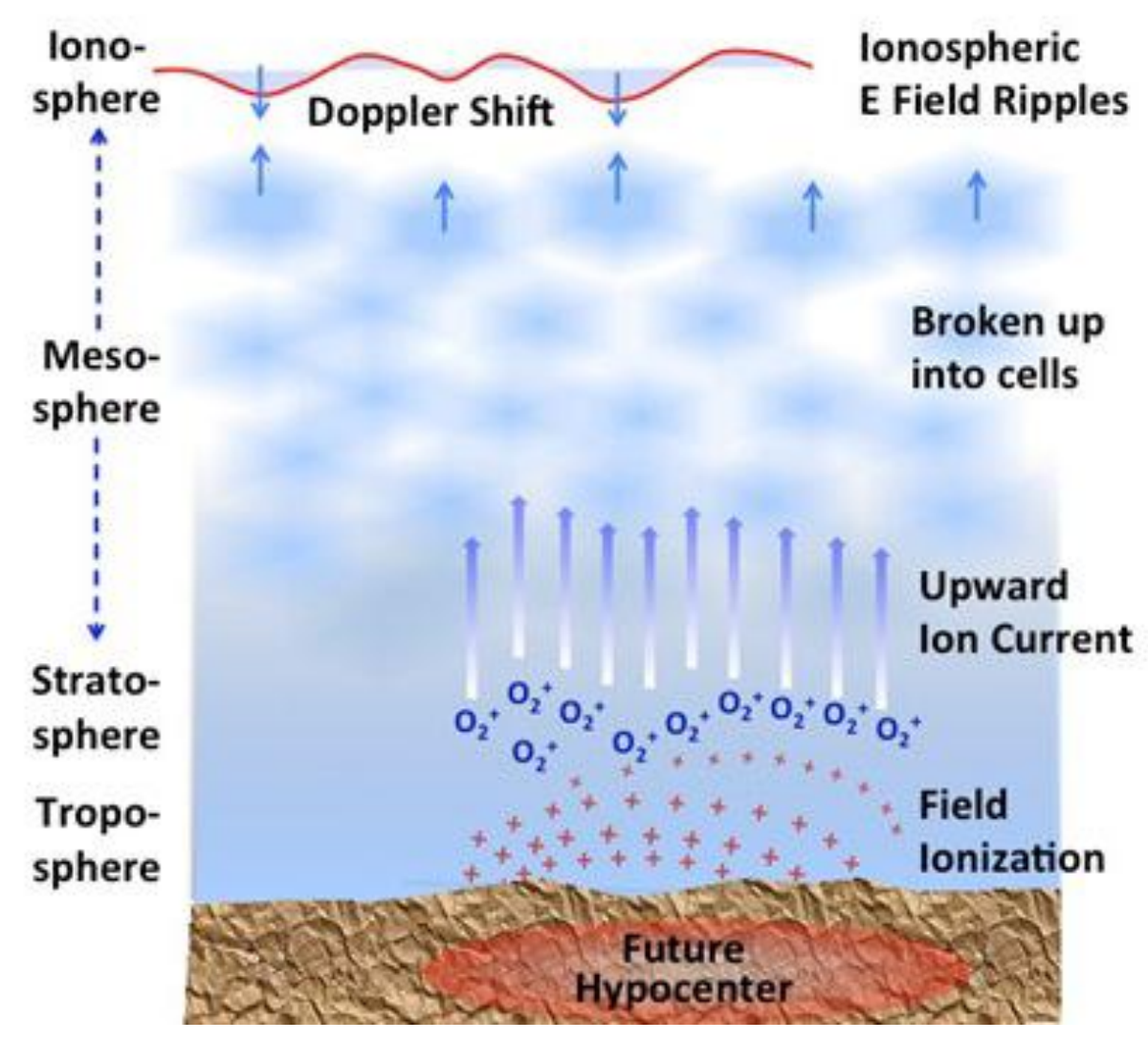

Figure 6: Illustration of pre-earthquake air ionisation at ground level above a future hypocentral region, leading to a bubble of positively charged air that will rise upward to stratospheric height and onto through the mesosphere, pulling down electrons in the ionospheric plasma [Freund 2013].

\section{Circadian Disfunction and ULF}

The flow of stress-activated positive hole charge carriers through the Earth's crust represents an electric current. Like any electric current it will naturally lead to the emission of electromagnetic (EM) waves, possibly over a wide frequency spectrum. While EM waves at frequencies above about $20 \mathrm{~Hz}$ are highly attenuated in the rock column, ultralow frequency (ULF) EM waves from about $20 \mathrm{~Hz}$, down to milliHz are able to travel over long distances and reach the Earth's surface. There is increasing evidence that EM waves in the ULF range may have a profound effect on organismal physiology and function [Freund \& Stolc 2014]. They can interact with or couple to biochemical reactions that are cyclic in nature, oscillating at frequencies that fall within the ULF range. Depending on phase and amplitude these ULF EM waves can affect biochemical 
reactions, which affect the circadian rhythm. Though circadian rhythms are highly conserved behaviour patterns, which vary over a $24 \mathrm{~h}$ cycle, there are reports describing fortuitous observations of unusual pre-earthquake animal and human responses. Mouse circadian rhythms were found to be affected [Yokoi et al. 2003; Li et al. 2009] and the daily rhythms of ants were reported to be disrupted prior to seismic activity [Berberich et al, 2013]. Cows, known to be sensitive to EM fluctuations in the extremely low frequency (ELF) range [Burda et al. 2009], have been observed to behave unusually prior to earthquakes, most notably in a case where an entire herd of cows laid down in unison [Whitehead \& Ulusoy 2013]. Childhood early waking was another pre-earthquake indicator reported in connection with the Kobe Earthquake and tentatively linked to ULF activity [Ikeya, M. \& Whitehead 2013]. Much more research is needed on how pre-seismic EM radiation can affect endogenous biological rhythms.

\section{Oxidation of Soil Organics to Toxic and/or Irritating Trace Gases}

Being defect electrons in the oxygen anion sublattice, positive hole charge carriers are chemically equivalent to $\mathrm{O}^{-}$. Having a high propensity to take over electrons, they are highly oxidizing. It is therefore not surprising to note that the arrival of the positive hole charge carriers at the Earth's surface can lead to oxidation reactions with, for instance, organic matter that is present in the soil. For example, days before the 2001 M 7.7 Gujarat earthquake in NW India carbon monoxide, CO, was released from the ground over a $100 \times 100 \mathrm{~km}^{2}$ region around the future epicentre in such high concentrations that it could be measured from satellite altitude [Singh et al. 2010]. CO is highly toxic to biological organisms, depending on concentration and length of exposure. Symptoms of carbon monoxide poisoning in humans include headache, nausea, and dizziness, confusion, weakness, and in more severe cases, respiratory and cardiac failure, hypoxia and, eventually, coma and death [Ernst \& Zibrak 1998]. Besides CO, other partly oxidized trace gases have to be considered as well, in particular formaldehyde and volatile ketones, which may have an irritating effect on animals.

\section{Air ionization}

When positive holes arrive at the Earth surface in sufficiently large numbers, they create microscopic but steep electric fields at the ground-to-air interface [Freund et al. 2009], steep enough to field-ionize air molecules, e.g. remove an electron, forming positive airborne ions such as $\mathrm{O}_{2}{ }^{+}$. This process has been demonstrated in the laboratory, and episodes of massive regional 
air ionization have observed in the field before major earthquakes in Japan, California and Peru [Bleier 2011].

Contrary to negative airborne ions, which have a beneficial or pleasant effect on humans, positive airborne ions reportedly have harmful or disagreeable effects, causing blood serotonin level to increase in animals and humans, thereby inciting physiological changes similar to what has been observed following antidepressant medication [Krueger \& Kotaka, 1969; Tom et al. 1981]. The symptoms are called the "serotonin syndrome", and they include confusion, restlessness, agitation, tremors or involuntary movements, hyperactivity, anxiety, hypertension, diarrhea and hypothermia [Mason et al. 2000; Boyer \& Shannon 2005]. The injection of massive amounts of positive airborne ions into the Earth's near-surface atmosphere prior to major earthquakes can be expected to have a profound effect on mammals and birds, in particular those living on the ground and in burrows. In addition, due to the way stress-activated positive hole charge carriers accumulate at the Earth's surface, the field-ionization of air molecules and production of positive airborne ions should be and indeed is more intense along ridges and mountain tops than in valleys [Freund 2013; Freund et al. 2009]. In this context it that, as marked by white circle in Figure 1, the 9-camera cluster in the Yanachaga National Park had been set up on a ridge, at $950 \mathrm{~m}$ elevation. This locality along a topographic high may have been inductive to pronounced air ionization and the pre-earthquake animal response.

Regrettably air ionization has not been monitored in the Yanachaga National Park. However, laboratory experiments [Bleier et al. 2010] and field data [Bleier et al.2011] indicate that the observed positive air ionization often occurs in series of spurs, sometimes lasting only a few minutes each, at other times lasting for 12-36 hrs, and reaching values 100 times higher or more than typical "fair weather" air ion concentrations, which are in the order of 200 ion pairs per $\mathrm{cm}^{3}$ at sea level [Rycroft \&Harrison 2008]. Episodes of high positive air ionization may be the cause of the anomalous behaviour of land animals reported here and before many other major seismic events [Tributsch 1981; Yokoi et al. 2003; Li et al. 2009; Whitehead \& Ulusoy 2013].

\section{Ionospheric perturbations}

The ionosphere is the boundary region between the atmosphere and the vacuum of space. Ionizing radiation from the sun and outer space ionizes the rarefied air, forming a plasma that consists of electrons, ions and neutral atoms. One widely studied type of pre-earthquake signals known as Total Electron Content (TEC) anomalies are ionospheric perturbations, consisting of an 
increase in electron density at the lower edge of the ionosphere [Liu et al. 2004]. Unusual animal behaviour coincident with perturbations in the ionosphere has been reported before [Grant \& Halliday 2010; Grant et al. 2011]. Though it is inconceivable that perturbations in the ionosphere 100-300 km above the surface of the Earth would trigger an animal response on the Earth's surface, it is plausible that pre-earthquake ionospheric perturbations and the pre-earthquake animal response are causally linked through the same process, namely through the generation of massive amounts of positive airborne ions at the ground-to-air interface.

Any air volume generated at the Earth's surface, laden with positive airborne ions, will expand upward to stratospheric heights as illustrated in Figure 6. In response the ionospheric plasma is expected to polarize in such a way that electrons will be pulled downward. The ensuing increase in TEC at the lower edge of the ionosphere, a TEC anomaly, affects the reflection of radio waves off the local ionosphere. The reflection is sensitive to TEC. The effect is most pronounced during the night hours, when the daytime solar influence on the ionosphere is minimal. In addition, due to dynamic processes expected to occur in the mesosphere [Freund 2013], the ionospheric perturbations will be granular in the time domain, contributing to a scatter of the radio waves reflected above a region, where a major earthquake is about to occur.

It thus appears understandable that the documented unusual animal behaviour in the Yanachaga National Park, probably driven by the generation of positive airborne ions at the ground-to-air interface, should coincide with an anomaly in the reflection of VLF waves off the lower edge of the ionosphere above the earthquake preparation zone, as documented in Figure 5.

On one hand, the animals in the Yanachaga National Park reacted to the increasing concentration of positive airborne ions at ground level, probably particularly pronounced along the ridge. On the other hand, the ionospheric perturbations developed some $300-400 \mathrm{~km}$ above the surface of the Earth because of the massive injection of positive airborne ions into the atmosphere, their upward transport through the stratosphere into the mesophere and the downward pull they exerted on the electrons in the ionosphere.

Although avoidance tests have not yet been carried out in the field with positive air ions, $\mathrm{CO}$ and other potentially irritating gases, animals will generally seek to avoid and move away from aversive stimuli in their environment. For example, animals will generally show avoidance responses to pollutants in their environments [Wentsel et al. 1977], so much so that they are often used as bioassays for the presence of pollutants [Black \& Birge 1980, Eriksson Wiklund et al. 2006]. Preliminary data on the aquatic flea Daphnia show that the organism moves away from hydrogen peroxide [Conlan \& Grant 2010], one of the compounds formed at the rock water 
interface when charge carriers activated in stressed rock cross into water [Balk et al. 2009]. Prior to the large earthquake in northern Peru, it is possible that due to release of gases and / or positive air ions, animals either moved away from the ridge, or reduced their overall activity, thereby causing changes in abundance as recorded by the camera traps.

An enhanced air ionisation at the ridge prior to the magnitude 7 Contamana earthquake may have caused the animals to escape to lower altitudes, where they would have been exposed to fewer positive airborne ions. The pre-earthquake anxiety, restlessness and escape reactions of domestic or captive animals, reported anecdotally for many decades, even centuries, may simply be due to the fact that confined animals tend to panic when they are unable to move away from aversive stimuli in their environment. If this correlation can be substantiated by systematically monitoring a wider range of reported pre-earthquake phenomena, this would lead to a better understanding of the premonitory abilities of animals.

\section{Acknowledgements}

All camera trap data in this publication were provided by the Tropical Ecology Assessment and Monitoring (TEAM) Network; a collaboration between Conservation International, the Missouri Botanical Garden, the Smithsonian Institution, and the Wildlife Conservation Society, and partially funded by these institutions, the Gordon and Betty Moore Foundation, and other donors. We thank two anonymous reviewers for their helpful comments on the manuscript.

\section{References}

Balk, M., M. Bose, Ertem Gözen, D. A. Rogoff, L. J. Rothschild, and F. T. Freund Oxidation of water to hydrogen peroxide at the rock-water interface due to stress-activated electric currents in rocks Earth Planetary Science Letters, 283(1-4), 87-92, (2009).

Batschelet, E. Circular statistics in biology (Vol. 371). London: Academic Press (1981).

Berberich, G., Berberich, M., Grumpe, A., Wöhler, C., and Schreiber, U. Early results of three-year monitoring of Red Wood ants' behavioral changes and their possible correlation with earthquake events. Animals 3, 63-84 (2013).

Black, J. A. \& Birge. W.J. An avoidance response bioassay for aquatic pollutants. National Technical Information Service, Springfield VA 2216, PB 80-180490, Research Report 123, (1980). 
Bleier, T., Dunson, C., Roth, S., Heraud, J. A., Lira, A. Ground-Based and Space-Based Electromagnetic Monitoring for Pre-Earthquake Signals, in Frontier of Earthquake Prediction Studies, edited by M. Hayakawa. (2011), p. 113-128.

Bleier, T., Dunson, C., Alvarez, C., Freund, F. and Dahlgren, R. Correlation of pre-earthquake electromagnetic signals with laboratory \& field rock experiments, Natural Hazards and Earth System Science. 10, (2010).

Boyer, E.W. and Shannon, M. The serotonin syndrome. New England Journal of Medicine 352, 1112-1120. (2005).

Brancelj, A, et al. "Consecutive earthquakes temporarily restructured the zooplankton community in an Alpine Lake." Annales de Limnologie-International Journal of Limnology. 4801 (2012).

Burda, H., Begall, S., Červený, J., Neef, J. and Němec, P. Extremely low-frequency electromagnetic fields disrupt magnetic alignment of ruminants. Proceedings National Academy of Science 106, 5708-5713 (2009).

Buskirk, R.E., Frohlich, C.L. and Latham, G.V. Unusual animal behavior before earthquakes: A review of possible sensory mechanisms. Reviews in Geophysics 19, 247-270 (1981).

Conlan, $\mathrm{H}$ and Grant R. Behavioural response in subterranean \& semi-aquatic invertebrates following experimental simulation of pre-seismic changes. EGU General Assembly Conference Abstracts 15, \#13863 (2010).

Dabas, R. S., Das, R. M., Sharma, K., \& Pillai, K. G. M. Ionospheric pre-cursors observed over low latitudes during some of the recent major earthquakes. Journal of Atmospheric and Solar-Terrestrial Physics, 69, 1813-1824 (2007).

Debruyn, A. M., \& Meeuwig, J. J. Detecting lunar cycles in marine ecology: periodic regression versus categorical ANOVA. Marine ecology. Progress series, 214, 307-310 (2001).

Derr, J.S. Earthquake lights: A review of observations and present theories. Bulletin of the Seismological Society of America 63, 2177-2187 (1973).

Eriksson Wiklund, A. K., Börjesson, T., and Wiklund, S. J. (2006). Avoidance response of sediment living amphipods to zinc pyrithione as a measure of sediment toxicity. Marine Pollution Bulletin 521 96-99 (2006). 
Ernst A., Zibrak J.D. Carbon monoxide poisoning. New England Journal of Medicine 339, 1603-8 (1998).

Freund, F. T. Earthquake Forewarning - a Multidisciplinary Challenge from the Ground up to Space, Acta Geophysica, 61, 775-807(2013).

Freund, F. T., Kulahci, I. G., Cyr, G., Ling, J., Winnick, M., Tregloan-Reed, J. et al. Air ionization at rock surfaces \& pre-earthquake signals. Journal of Atmospheric and SolarTerrestrial Physics, 71, 1824-1834 (2009).

Freund, F. and Stolc, V. Nature of Pre-Earthquake Phenomena \& their Effects on Living Organisms. Animals 3, 513-531 (2013).

Grant, R. A. and Halliday, T. Predicting the unpredictable; evidence of pre-seismic anticipatory behaviour in the common toad. Journal of Zoology, 281, 263-271 (2010).

Grant, R. A., Halliday, T., Balderer, W. P., Leuenberger, F., Newcomer, M., Cyr, G., and Freund, F. T. Ground water chemistry changes before major earthquakes and possible effects on animals, International Journal of Environmental Research and Public Health 8, 19361956. (2011),

Hayakawa, Masashi, Tetsuya Itoh, Katsumi Hattori, and Kiyohumi Yumoto. ULF electromagnetic precursors for an earthquake at Biak, Indonesia on February 17, 1996. Geophysical Research Letters 27, 1531-1534 (2000).

Hayakawa, T., Masashi, Y., Kasahara, T., Endoh, Y., Hobara, and Asai, S. The observation of Doppler shifts of subionospheric LF signal in possible association with earthquakes. Journal Geophysical Research - Space Physics. 117, A9 (2012).

Li, Y., Liu, Y., Jiang, Z., Guan, J., Yi, G et al. Behavioral change related to Wenchuan devastating earthquake in mice. Bioelectromagnetics, 30 613-620. (2009).

Ikeya, M. \& Whitehead, N. E. Unusual Childhood Waking as a Possible Precursor of the 1995 Kobe Earthquake. Animals, 3, 228-237 (2013).

Krueger, A. and Kotaka, S. The effects of air ions on brain levels of serotonin in mice. International Journal of Biometeorology 13, 25-38 (1969). 
Krueger, A. P., Andriese, P. C. and Kotaka, S. Small air ions: Their effect on blood levels of serotonin in terms of modern physical theory, International Journal of Biometeorology 12, 225-239 (1968).

Krueger, A. P. \& Reed, E.J. Biological impact of small air ions, Science 193, 1209-1213 (1976).

Liperovsky, V.A.et al. Modification of sporadic E-layers caused by seismic activity. Surveys in Geophysics 21, 449-486 (2000).

Liu, J. Y., Chuo, Y. J., Shan, S. J., Tsai, Y. B., Chen, Y. I. et al. Pre-earthquake ionospheric anomalies registered by continuous GPS TEC measurements. Annales Geophysicae 22, 15851593 (2004).

Liu, J. Y., Chen, Y. I., Chuo, Y. J., and Chen, C. S. A statistical investigation of preearthquake ionospheric anomaly. Journal Geophysical Research 111, A05304 (2006).

Maekawa, S., Horie, T., Yamauchi, T., Sawaya, T., Ishikawa, M. et al. A statistical study on the effect of earthquakes on the ionosphere, based on the subionospheric LF propagation data in Japan. Annales Geophysicae 24, 2219-2225 (2006).

Mason, P.J., Morris, V.A. and Balcezak, T.J. Serotonin syndrome. Presentation of 2 cases \& review of the literature. Medicine 79, 201 (2000).

Pulinets and S. Boyarchuk, K. Ionospheric Precursors of Earthquakes; Springer: Heidelberg, Germany. 350 pp. (2004).

Raulin, J. P., de Matos David, P. C., Hadano, R., Saraiva, A. C., Correia, E., \& Kaufmann, P. The South America VLF NETwork (SAVNET). Earth, Moon, and Planets 104, 247-261 (2009).

Ryabinin, G. V., Polyakov, Yu. S., Gavrilov, V. A. and Timashev, S. F. Identification of earthquake precursors in the hydrogeochemical \& geoacoustic data for the Kamchatka peninsula by flicker-noise spectroscopy. Natural Hazards and Earth System Science 11, 541548 (2011).

Rycroft, M. J., Harrison, R. G. Nicoll, K. A. and Mareev E. A. An overview of Earth's global electric circuit and atmospheric conductivity. Space Science Reviews, 137, 83-105. (2008). 
Saraf, A.K., Rawa, V., Banerjee, P., Choudhury, S., Panda, S.K. Satellite detection of earthquake thermal precursors in Iran. Natural Hazards 47, 119-135 (2008).

SenGupta, A., \& Ugwuowo, F. I. Asymmetric circular-linear multivariate regression models with applications to environmental data. Environmental and Ecological Statistics, 13, 299-309 (2006).

Shitov, A. V. Health of people living in a seismically active region. Man and the Geosphere, V. Florinski, ed., Nova Science Publishers, Inc., New York, 185-214 (2010).

Singh, R. P., Senthil Kumar, J., Zlotnicki, J. and Kafatos, M. Satellite detection of carbon monoxide emission prior to the Gujarat earthquake of 26 January 2001. Applied Geochemistry 25, 580-585 (2010).

Snarr, K.A. Seismic activity response as observed in mantled howlers (Alouatta palliata), Cuero y Salado Wildlife Refuge, Honduras. Primates 46, 281-285 (2005).

St-Laurent, F. The Saguenay, Québec, earthquake lights of November 1988-January 1989, Seismological Research Letters 71, 160-174 (2000).

Tom, G., Poole, M. F., Galla, J. and Berrier, J. The Influence of Negative Air Ions on Human Performance and Mood, Journal of the Human Factors and Ergonomics Society 23, 633-636 (1981).

Tramutoli, V., Cuomo, V., Filizzola, C., Pergola, N. and Pietrapertosa, C. Assessing the potential of thermal infrared satellite surveys for monitoring seismically active areas: The case of Kocaeli (Izmit) earthquake, August 17, 1999. Remote Sensing and Environment, 96, 409-426 (2005).

Tavera, H. A Report on the 24 August $2011 \mathrm{Mw}$ 7.0 Contamana, Peru, Intermediate-Depth Earthquake. Seismological Research Letters, 83, 1007-1013 (2012).

Tributsch, H. When the Snakes Awake: Animals and Earthquake Prediction; MIT Press: Cambridge, MA, USA, (1984) p. 264.

Tronin, A. A. Remote sensing and earthquakes: A review. Physics and Chemistry of the Earth 31, 138-142. (2006). 
Wentsel, R., McIntosh, A., McCafferty, W. P., Atchison, G., and Anderson, V. Avoidance response of midge larvae (Chironomus tentans) to sediments containing heavy

metals. Hydrobiologia 55, 171-175. (1977).

Whitehead, N.E., Ulusoy, U., Asahara, H. and Ikeya, M. Are any publicly reported earthquake precursors valid? Natural Hazards and Earth System Science 4, 463-468 (2004).

Whitehead, N.E. and Ulusoy, Ü. Macroscopic anomalies before the September 2010 $M=7.1$ earthquake in Christchurch, New Zealand. Natural Hazards and Earth System Science 13, 167-176. (2013).

Yokoi, S., Ikeya, M., Yagi, T., and Nagai, K. Mouse circadian rhythm before the Kobe earthquake in 1995. Bioelectromagnetics, 24, 289-291 (2003).

\section{Supplementary Information}

Camera traps used in this study and their locations in the Yanachaga National park in 2011. The periods used for the study were 24/7/11-25/8/11 for the earthquake period and 13/9/11-11/10/11 for the control period.

\begin{tabular}{|c|c|c|c|c|}
\hline Latitude & Longitude & $\begin{array}{l}\text { Camera Start } \\
\text { Date and Time } \\
\end{array}$ & $\begin{array}{l}\text { Camera End } \\
\text { Date and Time }\end{array}$ & $\begin{array}{l}\text { Camera Serial } \\
\text { Number }\end{array}$ \\
\hline \multicolumn{5}{|c|}{ EARTHQUAKE PERIOD } \\
\hline-10.353549 & -75.290374 & $\begin{array}{r}24 / 07 / 2011 \\
12: 19 \\
\end{array}$ & $\begin{array}{r}25 / 08 / 2011 \\
01: 22 \\
\end{array}$ & P800DE02121169 \\
\hline-10.378085 & -75.240306 & $\begin{array}{r}25 / 07 / 2011 \\
12: 34\end{array}$ & $\begin{array}{r}26 / 08 / 2011 \\
09: 25\end{array}$ & P800DE02121150 \\
\hline-10.353263 & -75.303721 & $\begin{array}{r}25 / 07 / 2011 \\
13: 32 \\
\end{array}$ & $\begin{array}{r}28 / 08 / 2011 \\
09: 37 \\
\end{array}$ & P800DE02121143 \\
\hline-10.365451 & -75.240332 & $\begin{array}{r}25 / 07 / 2011 \\
16: 25 \\
\end{array}$ & $\begin{array}{r}25 / 08 / 2011 \\
22: 37 \\
\end{array}$ & P800DE02121174 \\
\hline-10.340624 & -75.252806 & $\begin{array}{r}25 / 07 / 2011 \\
16: 51 \\
\end{array}$ & $\begin{array}{r}26 / 08 / 2011 \\
12: 14 \\
\end{array}$ & P800DE02121165 \\
\hline-10.327758 & -75.252762 & $\begin{array}{r}26 / 07 / 2011 \\
09: 50 \\
\end{array}$ & $\begin{array}{r}26 / 08 / 2011 \\
13: 58 \\
\end{array}$ & P800DE02121175 \\
\hline-10.353476 & -75.316129 & $\begin{array}{r}26 / 07 / 2011 \\
11: 04\end{array}$ & $\begin{array}{r}27 / 08 / 2011 \\
09: 02\end{array}$ & P800DE02121170 \\
\hline
\end{tabular}


Animal Activity prior to $\mathrm{M}=7$ Earthquake in Peru Physics and Chemistry of the Earth

\begin{tabular}{|c|c|c|c|c|}
\hline-10.353279 & -75.341277 & $\begin{array}{r}27 / 07 / 2011 \\
15: 23 \\
\end{array}$ & $\begin{array}{r}27 / 08 / 2011 \\
11: 40 \\
\end{array}$ & P800EE03123267 \\
\hline-10.353908 & -75.328533 & $\begin{array}{r}27 / 07 / 2011 \\
17: 22 \\
\end{array}$ & $\begin{array}{r}27 / 08 / 2011 \\
13: 45 \\
\end{array}$ & P800DE02121183 \\
\hline \multicolumn{5}{|c|}{ CONTROL PERIOD } \\
\hline-10.378304 & -75.290916 & $\begin{array}{r}06 / 09 / 2011 \\
13: 37 \\
\end{array}$ & $\begin{array}{r}13 / 10 / 2011 \\
05: 42 \\
\end{array}$ & P800DE02121159 \\
\hline-10.391034 & -75.290227 & $\begin{array}{r}06 / 09 / 2011 \\
14: 14 \\
\end{array}$ & $\begin{array}{r}15 / 10 / 2011 \\
14: 27 \\
\end{array}$ & P800DE02121184 \\
\hline-10.391395 & -75.302908 & $\begin{array}{r}06 / 09 / 2011 \\
16: 48 \\
\end{array}$ & $\begin{array}{r}14 / 10 / 2011 \\
17: 45 \\
\end{array}$ & P800DE02121193 \\
\hline-10.378868 & -75.316296 & $\begin{array}{r}09 / 09 / 2011 \\
10: 56 \\
\end{array}$ & $\begin{array}{r}15 / 10 / 2011 \\
14: 12 \\
\end{array}$ & P800DE02121175 \\
\hline-10.391095 & -75.316254 & $\begin{array}{r}09 / 09 / 2011 \\
12: 51 \\
\end{array}$ & $\begin{array}{r}11 / 10 / 2011 \\
21: 07 \\
\end{array}$ & P800DE02121180 \\
\hline-10.378378 & -75.303801 & $\begin{array}{r}11 / 09 / 2011 \\
13: 01 \\
\end{array}$ & $\begin{array}{r}15 / 10 / 2011 \\
07: 21 \\
\end{array}$ & P800DE02121146 \\
\hline-10.391609 & -75.32893 & $\begin{array}{r}11 / 09 / 2011 \\
14: 34 \\
\end{array}$ & $\begin{array}{r}16 / 10 / 2011 \\
12: 35 \\
\end{array}$ & P800DE02121154 \\
\hline-10.404759 & -75.316233 & $\begin{array}{r}13 / 09 / 2011 \\
10: 19 \\
\end{array}$ & $\begin{array}{r}19 / 10 / 2011 \\
10: 50 \\
\end{array}$ & P800DE02121143 \\
\hline-10.403808 & -75.303454 & $\begin{array}{r}13 / 09 / 2011 \\
11: 10 \\
\end{array}$ & $\begin{array}{r}17 / 10 / 2011 \\
21: 46 \\
\end{array}$ & P800DE02121169 \\
\hline-10.404162 & -75.290776 & $\begin{array}{r}13 / 09 / 2011 \\
16: 13 \\
\end{array}$ & $\begin{array}{r}19 / 10 / 2011 \\
00: 46 \\
\end{array}$ & P800DE02121198 \\
\hline
\end{tabular}

